OPEN ACCESS

Edited by:

Lizza E. L. Hendriks, Maastricht University Medical Centre,

Netherlands

Reviewed by: Sébastien Roger, Université de Tours, France Elena Adinolfi,

University of Ferrara, Italy

*Correspondence:

Ruchong Chen

chen_rch@163.com

Nanshan Zhong

nanshan@vip.163.com

Peter V. Dicpinigaitis

pdicpin@gmail.com

Specialty section: This article was submitted to

Thoracic Oncology, a section of the journal

Frontiers in Oncology

Received: 07 April 2021 Accepted: 07 June 2021 Published: 29 June 2021

Citation:

Mai Y, Guo Z, Yin W, Zhong N, Dicpinigaitis PV and Chen $R$ (2021) P2X Receptors: Potential Therapeutic

Targets for Symptoms Associated With Lung Cancer - A Mini Review.

Front. Oncol. 11:691956.

doi: 10.3389/fonc.2021.691956

\section{P2X Receptors: Potential Therapeutic Targets for Symptoms Associated With Lung Cancer - A Mini Review}

\author{
Yonglin Mai ${ }^{1}$, Zhihua Guo ${ }^{2}$, Weiqiang Yin $^{2}$, Nanshan Zhong ${ }^{1 *}$, Peter V. Dicpinigaitis ${ }^{3 *}$ \\ and Ruchong Chen ${ }^{1 *}$ \\ 1 Department of Allergy and Clinical Immunology, State Key Laboratory of Respiratory Disease, National Clinical Research \\ Center for Respiratory Disease, Guangzhou Institute of Respiratory Health, The First Affiliated Hospital of Guangzhou Medical \\ University, Guangzhou, China, ${ }^{2}$ Department of Thoracic Surgery, State Key Laboratory of Respiratory Disease, National \\ Clinical Research Center for Respiratory Disease, Guangzhou Institute of Respiratory Health, The First Affiliated Hospital of \\ Guangzhou Medical University, Guangzhou, China, ${ }^{3}$ Department of Medicine, Albert Einstein College of Medicine \& \\ Montefiore Medical Center, Bronx, NY, United States
}

Symptoms associated with lung cancer mainly consist of cancer-associated pain, cough, fatigue, and dyspnea. However, underlying mechanisms of lung cancer symptom clusters remain unclear. There remains a paucity of effective treatment to ameliorate debilitating symptoms and improve the quality of life of lung cancer survivors. Recently, extracellular ATP and its receptors have attracted increasing attention among researchers in the field of oncology. Extracellular ATP in the tumor microenvironment is associated with tumor cell metabolism, proliferation, and metastasis by driving inflammation and neurotransmission via P2 purinergic signaling. Accordingly, ATP gated P2X receptors expressed on tumor cells, immune cells, and neurons play a vital role in modulating tumor development, invasion, progression, and related symptoms. P2 purinergic signaling is involved in the development of different lung cancer-related symptoms. In this review, we summarize recent findings to illustrate the role of P2X receptors in tumor proliferation, progression, metastasis, and lung cancer- related symptoms, providing an outline of potential antineoplastic activity of $\mathrm{P} 2 \mathrm{X}$ receptor antagonists. Furthermore, compared with opioids, P2X receptor antagonists appear to be innovative therapeutic interventions for managing cancer symptom clusters with fewer side effects.

Keywords: ATP, P2X receptors, antagonist, cancer-related symptoms, tumor microenvironment

Abbreviation: ATP, adenosine triphosphate; BDNF, brain-derived neurotrophic factor; $\mathrm{Ca}^{2+}$, calcium; CNS, central nervous system; CRF, Cancer-related fatigue; CRP, C-reactive protein; HPA, hypothalamic-pituitary-adrenal; NSCLC, non-small cell lung cancer; IL, interleukin; KO, knockout; LPS, lipopolysaccharide; SP, substance P; TNF, tumor necrosis factor; TME, tumor microenvironment; VNUT, vesicular nucleotide transporter. 


\section{INTRODUCTION}

Lung cancer is one of the most common types of cancer, annually causing about 1.8 million deaths worldwide (1). The early detection of lung cancer and improvements in treatment have increased the survival of patients (2). The number of lung cancer survivors is anticipated to increase to 673,000 by 2026 (3). Cancer survivors experience a complex profile of diverse symptomatology, adversely affecting their quality of life. Consequently, patients complain of a wide variety of symptoms that are mainly categorized as physical and psychological symptoms. Dodd et al. defined the cancer-related symptoms as "symptom clusters" (4). Specifically, in lung cancer patients, respiratory clusters are identified as pain, cough, fatigue, and dyspnea $(5,6)$. However, cancer patients present multiple symptoms, and lung cancer studies illustrate the complex correlations between different clusters of symptoms. Clinically, opiate-derivative treatment is the mainstay of the drug management of cancer-related symptoms, such as pain, fatigue, cough, and dyspnea (7-9), but benefits relatively few cancer patients. Currently, physicians prescribe opioid therapy without high-quality evidence, which might heighten the potential risk of opioid-induced side effects in patients with cancer, such as sedation, respiratory depression, tolerance development, and gastrointestinal dysmotility $(10,11)$. Therefore, an in-depth longitudinal exploration of lung cancer related-symptoms is essential to developing a targeted intervention to improve the quality of life of cancer survivors.

Accumulated adenosine triphosphatez (ATP) and other extracellular nucleotides shape tumor microenvironment (TME), significantly influencing cancer proliferation, progression, tumor/immune-cell cross-talk, and related symptoms (12, 13). Accordingly, receptors for extracellular ATP (G-coupled P2Y and P2X ion channels) are involved in driving several functions during tumor initiation and development. To note, the ATP-gated P2X purine family consists of seven subtypes (P2X1-7 receptors) (14), with some being demonstrated to directly or indirectly regulate tumor proliferation, angiogenesis, and dissemination. For example, $\mathrm{P} 2 \mathrm{X} 4, \mathrm{P} 2 \mathrm{X} 5$, and $\mathrm{P} 2 \mathrm{X} 7$ receptors exist on the membrane of multiple tumor cells, such as non-small cell lung cancer, colorectal cancer, bladder cancer, renal cancer, as well as haematological malignancies, to promote the proliferation and metastatic potential of the tumor (15-20). In particular, the P2X7 receptor is the subtype associated with cancer proliferation (21), and its activation promotes VEGF-dependent angiogenesis and extracellular matrix degradation via protease releasing and cytoskeletal remodeling, playing a prometastatic role in cancer (22-25). A study analyzing P2X7 mRNA expressions in patients with non-small cell lung cancer (NSCLC) revealed an upregulated P2X7 expression in bronchoalveolar lavage fluid of tumor with distant metastases (20). To understand its proliferative and prometastatic roles in tumor, the potential interaction of P2X7R splice variants and cancer cell determination should be discussed. Evidence which appeared on non-pore functional P2X7R (nfP2X7) and P2X7B isoforms in a wide range of tumors suggested that lacking the pore-forming cytotoxic activity enables them to retain a distinct pro-survival trophic property and promote oncologic progression $(26,27)$. Collectively, the purinergic/adenosinergic system regulates the growth, metastasis, and invasion of cancer, thus rendering P2X purine receptors as potential targets for tumor therapy (13).

More data demonstrated that ATP, its hydrolyzation products, ectonucleotidases, (degrading enzymes, like CD39), and purinergic receptors play a significant role in the modulation of the TME immune component. Extracellular nucleotides and P2 purinergic signaling drive the recruitment of inflammatory cells (such as macrophages, neutrophils, DCs, and microglia) and adjust immunomodulation on tumor sites (12). The purinergic/ adenosinergic system modulates cytokine gene expression within the nervous and immune systems and also regulates the secretion of pro-inflammatory cytokines, such as interleukin (IL)-1 $\beta$, IL-6, and tumor necrosis factor (TNF)- $\alpha$ (28-30). With the collaboration between anti-CD39 and P2X7 activation in the TME, immune cells can bring an antitumor response by P2X7mediated NLRP3 inflammasome activation and IL-18 release from myeloid cells $(31,32)$. The relationship of receptor polymorphism and inflammatory responses (including NLRP3 inflammasome activation and IL- $1 \beta$ and IL- 8 release) was reported by $\mathrm{Hu}$ and colleagues (33). Besides purinergic receptors' involvement, sensory nerves are also found to be involved in the stimulation of cancer progression, indicating the existence of tumor-nerve interactions. Reportedly, the denervation of vagus nerves and ablation of sensory neurons inhibit tumor initiation and progression in mouse models with cancer $(34,35)$. Herein, we hypothesize that ATP acts as a pivotal transmitter to convey sensory stimuli from peripheral nerves to the CNS, to activate $\mathrm{P} 2 \mathrm{X}$ purine receptors ( $\mathrm{P} 2 \mathrm{X} 2, \mathrm{P} 2 \mathrm{X} 3, \mathrm{P} 2 \mathrm{X} 4$, and $\mathrm{P} 2 \mathrm{X} 7$ receptors) expressed on sensory nerve fibers and microglia, to enhance peripheral neural information transmission, as well as to sensitize the CNS (36). A study reinforced this hypothesis that ATP is transported into secretory vesicles in primary afferents and spinal cord by vesicular nucleotide transporter (VNUT) to stimulate related purinergic receptors (i.e. P2X4R), which has been proved in genetic knockout or VNUT inhibitors to relieve neuropathic and inflammatory pain sensation (37). Marked upregulation of P2X4 receptors was detected in $\mathrm{C} 6$ glioma tissue; these receptors also activate microglia in the central nervous system (CNS) and tumor-associated macrophages in the peripheral system to mediate inflammatory reactions (38). Taken together, those evidence highlighted the crosstalk between nervous and immune systems via $\mathrm{P} 2 \mathrm{X}$ pathways. Thus, dissecting the neuro-immune pathways via $\mathrm{P} 2 \mathrm{X}$ receptors may provide new therapeutic strategies in cancer treatment.

Intriguingly, a high concentration of extracellular ATP in the tumor milieu is able to regulate cancer cell death by exploiting ATP-dependent cytotoxicity (39). Purinergic receptors' cytotoxic functions are shown under the condition of persistent overstimulation of high levels of ATP. Prolonged stimulation of P2X7 receptor via high dosage ATP leads to the opening of a larger conductance membrane pore, which in turn induces tumor cell 
death and inhibits tumor growth (15). Sustained opening of the P2X7R macropore stimulated by high extracellular ATP concentration in the TME triggers caspase- 3 cleavage and then leads to membrane progression and ultimate cell death via different pathways $(15,40)$. Therefore, it makes sense that the application of P2X receptor agonists, such as ATP and P2X receptor activators, restrains tumor growth. Preclinical cancer models revealed the efficacy of administration of ATP at a high dosage to suppress tumor growth $(41,42)$. Clinical trials in treating advanced NSCLC patients with intravenous infusion of ATP showed a significant improvement in quality of life and cachexia effects (43). A recent study demonstrated the proapoptotic mechanism of $\mathrm{P} 2 \mathrm{X} 7 \mathrm{R}$ stimulation, showing that combined with an $\alpha \mathrm{PD}-1$ immune checkpoint inhibitor, HEI3090, as a P2X7R agonist, activates tumor regression in $80 \%$ of Lewis lung carcinoma tumor-bearing mice. During tumor inhibition, P2X7R's cytotoxic activities were described in immune cells, especially dendritic cells, to release proinflammatory cytokines (IL-1 $\beta$ and IL-18) via an NLRP3dependent pathway (44). Despite the promising efficacy of P2XR agonist therapy being displayed, side effects should be noticed. In intravenous ATP infusions, dyspnea emerged as the most common side effects, followed by chest tightness, urge to take a deep breath, and cardiac disorders (45). We speculated that ATP agonists activate various $\mathrm{P} 2 \mathrm{X}$ receptors, especially $\mathrm{P} 2 \mathrm{X} 3 \mathrm{R}, \mathrm{P} 2 \mathrm{X} 4 \mathrm{R}$, and $\mathrm{P} 2 \mathrm{X} 7 \mathrm{R}$, in other tissues or organs to induce a series of symptoms. Their predominant roles are also reported in mediating immune responses and the nervous system (see below). Based on the aforementioned side effects, it is tempting to hypothesize that compared with P2X antagonists/ inhibitors, therapies based on P2X agonists would get patients more exposed to more risks of discomforts (i.e. pain sensations, dyspnea, immune system disorders). Whether P2X agonists or antagonists should be adopted depends on multiple factors, including genetic differences $(46,47)$, different cancer types and onset sites, P2X receptor tumor expression (48), and cancer-associated symptoms (pain, dyspnea, fatigue, etc.). More studies are required to elucidate further use of $\mathrm{P} 2 \mathrm{X}$ receptors-targeted therapies in cancer patients in the future.

A large number of studies have highlighted the role of ATP and P2X purine receptors on the development and progression of cancer. Thus, it could be speculated that a putative P2Xdependent mechanism affects cancer-related symptoms, including pain, fatigue, cough, and dyspnea. Herein, we summarize the related findings on the potential correlation between different types of cancer symptom clusters and P2X purine signaling, providing an outline for the potential treatment of distressing cancer-related symptoms using $\mathrm{P} 2 \mathrm{X}$ receptor antagonists (Figure 1).

\section{CANCER-RELATED PAIN}

Half of the cancer patients may experience different levels of pain, especially those with the middle and advanced stages of cancer (49). The growth, proliferation, migration, and invasion of tumors compress and damage peripheral nerves, and then sensitize peripheral sensors and transmit the sensation of pain (50). Bone cancer pain may be an applicable example, which results from primary bone cancer and the metastasis of other common cancers, such as lung cancer, breast cancer, and prostate cancer. Tumor infiltration in the bone compresses and damages sensory nerve fibers, which in turn aggravates the pain. Furthermore, immune cells (such as lymphocytes and macrophages) play a critical role in the tumorigenic site by releasing inflammatory cytokines (such as TNF-a, IL-1, IL-6, and substance P (SP) (51). Based on these perspectives, cancer pain is related to nociceptive pain, neuropathic pain, and inflammatory pain.

In the tumor microenvironment, $\mathrm{ATP}$ and $\mathrm{P} 2 \mathrm{X}$ receptors were detected in patients with cancer pain (52). Increased extracellular ATP triggers pain via activation of different P2X receptors involved in nociceptive, neuropathic, and inflammatory pain. Specifically, ATP-gated P2X3 and P2X2/3 receptors selectively expressed in primary afferent nerves (vagal $\mathrm{C}$ fibers and $\mathrm{A} \delta$-fibers) and afferent sensory neurons (i.e. dorsal root ganglia, trigeminal nerve, inferior ganglion of the vagus nerve, and glossopharyngeal nerve) $(53,54)$ participate in the development and transmission of pain signals with respect to chronic inflammatory pain, neuropathic pain, and cancer pain $(55,56)$. Several studies have shown upregulation of P2X3 receptors in the dorsal root ganglion of animals that experienced bone cancer pain (57-59). Data also support that homomeric $\mathrm{P} 2 \mathrm{X} 3$ and heteromeric $\mathrm{P} 2 \mathrm{X} 2 / 3$ receptors are involved in the generation of bone cancer pain perception (60, 61). A-317491, a P2X3 receptor antagonist, could efficiently relieve cancer-induced bone pain related to early-stage tumors. However, it had limited effects on inhibiting the progression of the tumor from an early to an advanced stage (62). Similarly, suramin, a broad spectrum P2 receptor antagonist, reduced prostate-specific antigen levels, pain, and disease progression but the mechanism of pain reduction remains unknown. Another selective $\mathrm{P} 2 \mathrm{X} 3$ and $\mathrm{P} 2 \mathrm{X} 2 / 3$ receptor antagonist, AF353 , had an efficacious pain-easing function but could not prevent cancer-induced bone destruction. With the application of in vivo electrophysiology, AF-353 administration on the spinal cord of animals with bone cancer reduced the neuronal hyperexcitability to mechanical and chemical stimuli, suggesting that the central nervous system was involved in the cancer pain (59).

Furthermore, P2X4 expressed on microglial cells within the CNS and P2X7 expressed on nerve cells as well as macrophages in the periphery participate in the etiology of cancer pain. The upregulation of $\mathrm{P} 2 \mathrm{X} 4$ receptors in spinal microglia induces the release of brain-derived neurotrophic factor (BDNF), a shortterm promoter of neuropathic pain (63). P2X7 receptors expressed in spinal microglia participated in the development of advanced cancer pain by modulating ATP release and proinflammatory cytokine production $(64,65)$. C57BL/6J P2X7 receptor knockout $(\mathrm{KO})$ mice had absent responsiveness to thermal and mechanical stimuli, and their macrophages did not secrete cytokines (for example, IL-1 $\beta$ ) under the 


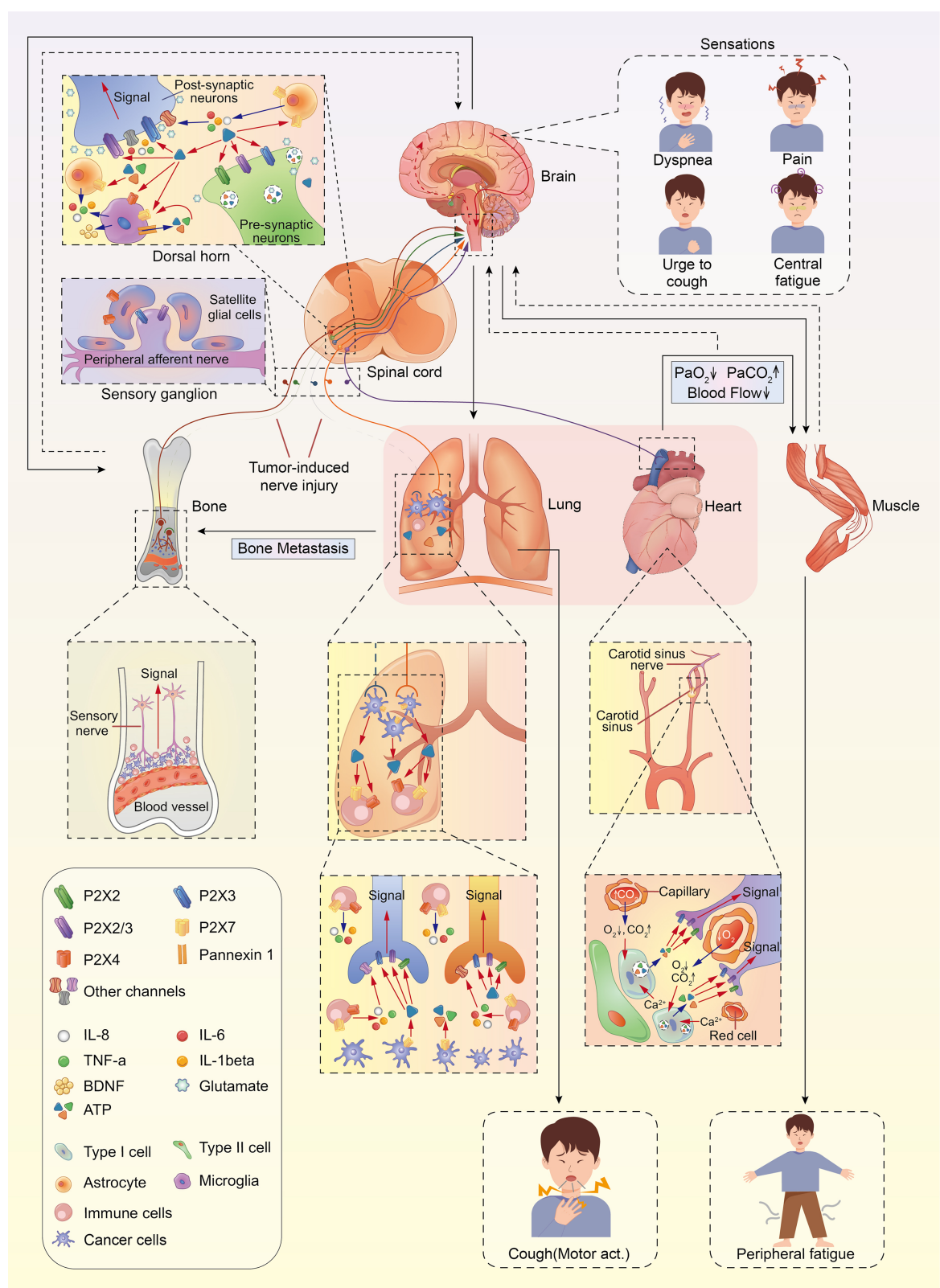

FIGURE 1 | The anatomical and molecular mediators of lung cancer symptom cluster. $\mathrm{Ca}^{2+}$, calcium; ATP, adenosine triphosphate; BDNF, brain-derived neurotrophic factor.

stimulation of lipopolysaccharide (LPS), indicating that P2X7 receptors enhance nociceptive transmission by elevating the secretion of cytokines via macrophages (66). Conversely, $\mathrm{BALB} / \mathrm{cJ}$ P2X7R KO mice had pain-related behaviors after bone cancer induction. Compared with wild-type counterparts, they presented an earlier onset for pain-related behaviors and a significantly severe pain phenotype (67). Different genetic backgrounds of mice strains might account for discrepant results. C57BL/6 and BalbcJ P2X7R deficient mice might express different $\mathrm{P} 2 \mathrm{X} 7$ polymorphisms that would cause variability in phenotypes and presentations (e.g. pain-related behaviours, bone remodeling) in comparison of WT type littermates $(47,68-71)$. Besides animal models, two human chronic pain cohort (one with pain after mastectomy and the other with osteoarthritis), revealed a genetic association between intensive chronic pain and the hyperfunctional variant of His 270 (rs7958311) allele of P2X7R, suggesting that selective blockade aiming at P2X7R pore formation also seems to be an innovative and personal therapeutic strategy for individual chronic pain (47). 
The knockdown of $\mathrm{P} 2 \mathrm{X} 7$ receptors with the utilization of selective or specific antagonists (A-438079, A-740003, and A839977 ) benefits cancer pain by reducing the release of cytokine, such as Il-1 $\beta(66,72,73)$. Another study reported that acute treatment with A-438079 failed to reduce pain-related behaviors in a mouse model of bone cancer pain (67). Current evidence suggests that the P2X4 receptor expressed on microglia induces spinal inflammatory pain and neuropathic pain and releases cytokines $(74,75)$. However, only a few studies have reported the role of $\mathrm{P} 2 \mathrm{X} 4$ receptors in the treatment of cancer pain. A recent study has shown that RS-504393, a selective antagonist of the chemokines C-C motif receptor 2 (CCR2), reduced the expression of $\mathrm{P} 2 \mathrm{X} 4 \mathrm{R}$ in the spinal cord and relieved bone cancer pain, rendering $\mathrm{P} 2 \mathrm{X} 4 \mathrm{R}$ a potential target for cancer pain therapy (76).

Kyushu University and Nippon Chemiphar Co. Ltd initiated a Phase 1 clinical trial of NC-2600 in 2016 to elucidate its efficacy in chronic neuropathic pain (to date, there is no information on the structure or preclinical data). Although P2X7 antagonists, such as AZD9056 and CE-224,535 were well tolerated in Phase 1 clinical studies, they showed insignificant efficacy in treating rheumatoid arthritis in Phase 2 clinical trials. Another P2X7 antagonist, AZD9056, has the therapeutic potential to decrease Crohn's disease activity index along with improvement in chronic abdominal pain, as shown in a Phase 2 a clinical study of Crohn's disease (Table 1). However, only a few randomized, double-blind, placebo-controlled clinical studies have demonstrated the efficacy and safety of $\mathrm{P} 2 \mathrm{X}$ receptors in treating cancer pain. Collectively, the usage of P2X antagonists might present a promising therapeutic strategy for cancer-associated pain compared to the current, commonly-used agents, such as opioids (53).

\section{CANCER-RELATED COUGH}

A persistent cough is a common symptom affecting over $50 \%$ of patients with lung cancer with a considerably adverse impact on quality of life (77). Cough can be evoked by activation of vagal afferent nerves innervating the airways and lungs-C-fibers (chemically) and A $\delta$-fibers (mechanically) (78, 79). In lung

TABLE 1 | Clinical Studies of P2X Receptor Antagonists.

\begin{tabular}{|c|c|c|c|c|c|c|}
\hline Targets & Compound & Trial Identifier & Responsible Party & Development & Indications & Estimated Completion \\
\hline $\mathrm{P} 2 \mathrm{X} 4 \mathrm{R}$ & NC-2600 & $\begin{array}{l}\text { Pharmaceuticals and Medical } \\
\text { Devices Agency (PMDA) }\end{array}$ & $\begin{array}{l}\text { Kyushu University, Nippon } \\
\text { Chemiphar Co., Ltd }\end{array}$ & Phase 1 & Neuropathic pain & $\begin{array}{l}\text { Completed (no results posted), } \\
\text { www.chemiphar.co.jp }\end{array}$ \\
\hline \multirow[t]{11}{*}{ P2X3R } & $\begin{array}{l}\text { AF-219/MK- } \\
\text { 7264/ } \\
\text { Gefapixant }\end{array}$ & NCT03449134 (COUGH-1) & $\begin{array}{l}\text { Merck Sharp and Dohme } \\
\text { Corp. }\end{array}$ & Phase 3 & Chronic cough & $\begin{array}{l}\text { Completed (published in an abstract } \\
\text { form) }\end{array}$ \\
\hline & & NCT03449147 (COUGH-2) & $\begin{array}{l}\text { Merck Sharp and Dohme } \\
\text { Corp. }\end{array}$ & Phase 3 & Chronic cough & $\begin{array}{l}\text { Completed (published in an abstract } \\
\text { form) }\end{array}$ \\
\hline & & NCT02477709 & $\begin{array}{l}\text { Afferent Pharmaceuticals, } \\
\text { Inc. }\end{array}$ & Phase 2 & $\begin{array}{l}\text { Idiopathic Pulmonary } \\
\text { Fibrosis (IPF) }\end{array}$ & Completed (results posted online) \\
\hline & & NCT02502097 & $\begin{array}{l}\text { Afferent Pharmaceuticals, } \\
\text { Inc. }\end{array}$ & Phase 2 & IPF-associated cough & Completed (results posted online) \\
\hline & $\begin{array}{l}\text { BAY } \\
1817080\end{array}$ & NCT04562155 & Bayer & Phase 1/2 & Chronic cough & $\begin{array}{l}\text { Primary Completion: Jun, } 2021 \\
\text { Study Completion: Jul, } 2021\end{array}$ \\
\hline & & NCT03310645 & Bayer & Phase 1/2 & Chronic cough & Completed (no results posted) \\
\hline & & NCT04614246 & Bayer & Phase 2 & $\begin{array}{l}\text { Pain related to } \\
\text { endometriosis }\end{array}$ & $\begin{array}{l}\text { Recruiting } \\
\text { Primary Completion: Aug. } 2022 \\
\text { Study Completion: Sep. } 2023\end{array}$ \\
\hline & & NCT04641273 & Bayer & Phase 2 & $\begin{array}{l}\text { Diabetic neuropathic } \\
\text { pain }\end{array}$ & $\begin{array}{l}\text { Recruiting } \\
\text { Primary Completion: Jun.2023 } \\
\text { Study Completion: Jul.2023 }\end{array}$ \\
\hline & BLU-5937 & NCT03979638 (RELIEF) & Bellus Health Inc. & Phase 2 & Chronic cough & $\begin{array}{l}\text { Terminated early because of the } \\
\text { impact of COVID-19 on the trial } \\
\text { activities (no results posted) }\end{array}$ \\
\hline & BAY1902607 & NCT03535168 & Bayer & Phase 1/2 & Chronic cough & Completed (no results posted) \\
\hline & S-600918 & NCT04110054 & Shionogi Inc. & Phase 2b & Chronic cough & Completed (no results posted) \\
\hline \multirow[t]{7}{*}{ P2X7R } & AZD9056 & $\begin{array}{l}\text { Eudra-CT Number: } 2005- \\
\text { 002319-26, Sponsor Protocol } \\
\text { Number: D8830C00002 }\end{array}$ & AstraZeneca AB & Phase 2a & $\begin{array}{l}\text { Chronic abdominal } \\
\text { pain related to } \\
\text { Crohn's disease (CD) }\end{array}$ & Completed (results posted online) \\
\hline & & NCT00520572 & AstraZeneca AB & Phase 2 & Rheumatoid Arthritis & Completed (results posted online) \\
\hline & CE-224,535 & NCT00628095 & Pfizer Inc. & Phase 2/3 & Rheumatoid Arthritis & Completed (no results posted) \\
\hline & & NCT00418782 & Pfizer Inc. & Phase 2 & Osteoarthritis pain & Completed (no results posted) \\
\hline & GSK1482160 & NCT00849134 & GlaxoSmithKline & Phase 1 & Inflammatory pain & Completed (no results posted) \\
\hline & $\begin{array}{l}\text { JNJ- } \\
54175446\end{array}$ & NCT04116606 & $\begin{array}{l}\text { CCTU-Core, } \\
\text { Cambridgeshire and } \\
\text { Peterborough NHS } \\
\text { Founation Trust }\end{array}$ & Phase 2 & $\begin{array}{l}\text { Major depression } \\
\text { disorder, inflammation }\end{array}$ & $\begin{array}{l}\text { Recruiting } \\
\text { Primary Completion: May, } 2021 \\
\text { Study Completion: Dec. } 2021\end{array}$ \\
\hline & & NCT02902601 & $\begin{array}{l}\text { Janssen Research and } \\
\text { Development, LLC. }\end{array}$ & Phase 1 & $\begin{array}{l}\text { Major depression } \\
\text { disorder }\end{array}$ & Completed (no results posted) \\
\hline
\end{tabular}


cancer, coughing is often provoked by the tumor (especially endobronchial neoplasms)-stimulating bronchial receptors and/ or by the inflammatory responses of the tumor activating afferent nerve fibers in the airways (80). In one study, lung cancer relatedcough remained refractory while other cancer symptoms were managed adequately in clinical practice (81). Moreover, chronic dry cough is present in about $25-50 \%$ of patients after undergoing lung cancer surgery $(82,83)$. Despite such high prevalence, current practice on treating cancer-related cough is empirical without high-quality evidence. Oral opioids are widely used in managing patients with cancer but with significant side effects (81).

ATP-gated P2X3 receptors are localized on the terminals of vagal $C$ fibers innervating the lungs and airways and are activated by ATP released into the airway in guinea pigs $(84,85)$. In addition, the terminals of A $\delta$-fibers express P2X3 receptors (53). In the airways and lungs, ATP acts as a trigger of the cough reflex via stimulation of $\mathrm{P} 2 \mathrm{X} 3$ and $\mathrm{P} 2 \mathrm{X} 2 / 3$ receptors expressed on the vagal sensory neurons central to the cough reflex $(86,87)$. Kamei et al. observed that when exposed to tussive stimuli, such as ATP and histamine aerosols, cough reflex sensitivity was enhanced via $\mathrm{P} 2 \mathrm{X}$ receptor signals in guinea pigs. This effect could be attenuated by pretreatment with TNP-ATP, a potent $\mathrm{P} 2 \mathrm{X} 3$ antagonist, in guinea pigs $(88,89)$. Morice et al. reported the ability of the $\mathrm{P} 2 \mathrm{X} 3$ receptor antagonist gefapixant (formerly named AF-219 and MK-7264) in alleviating cough induced by ATP and ultrasonically-nebulized distilled-water, but not capsaicin and citric acid (90). Bonvini et al. identified that TRPV4-ATP-P2X3 interaction was involved in cough hypersensitivity in guinea pig conscious cough models (91). These findings suggest that the $\mathrm{P} 2 \mathrm{X} 3$ pathway might underlie cough hypersensitivity in chronic refractory cough, supporting a potential therapeutic role in the treatment of lung cancer-induced chronic cough.

In the tumor microenvironment, elevated levels of ATP and adenosine due to degradation of extracellular ATP were observed during cancer development, which might subsequently activate purinergic receptors that are fed to the central nervous system (12). Recent studies have demonstrated the efficacy of P2X receptor antagonists in the management of chronic cough and showed an association between ATP and cough via purinergic signaling. Gefapixant, a first-in-class selective antagonist of the P2X3 and $\mathrm{P} 2 \mathrm{X} 2 / 3$ receptors, significantly inhibited ATP-evoked cough in patients with chronic cough (90). Furthermore, gefapixant showed a significant reduction in cough frequency, as assessed by randomized, double-blind, placebo-controlled Phase 2 trials (92, 93). Recently, two Phase 3 randomized controlled trials (COUGH-1 and COUGH-2) of gefapixant in refractory chronic cough and unexplained chronic cough, evaluating more than 2000 patients, have been completed (94). Compared to placebo, treatment with 45 mg gefapixant demonstrated a significant reduction in 24-h cough frequency in patients (95). However, the loss of taste was an adverse event accompanied by incremental doses of gefapixant $(92,93)$. Reportedly, the adverse events with gefapixant $45 \mathrm{mg}$ were mostly related to altered taste (95).

Another P2X3-receptor antagonist, BLU-5937 demonstrated safety and tolerability in the Phase 1 clinical trial (96), while the
Phase 2 clinical trial was delayed due to the COVID 19 pandemic. According to the current data released by the sponsor, this trial failed to meet the primary endpoints for any doses, although BLU-5937 was well-tolerated and its efficacy in reducing awake cough frequency was also found in a subgroup of patients with high cough counts at baseline. Two other P2X3selective antagonists, BAY 1817080 and S-600918, have shown antitussive effects in completed Phase 2 trials $(97,98)$. BAY1902607 underwent a Phase I/II proof-of-concept clinical trial. Although it has been announced as complete, the results have not yet been posted (Table 1).

In light of published and ongoing promising data with at least four clinical programs involving P2X3 receptor-antagonists in treating chronic refractory cough (90-98), and with extracellular ATP and its receptors having been shown to modulate tumor development, invasion progression, and tumor microenvironment, P2X receptor antagonists may be expected also to exert an antitussive effect in lung cancerrelated cough. Further studies in this area are eagerly awaited.

\section{CANCER-RELATED FATIGUE}

Cancer-related fatigue (CRF) is one of the cancer cluster symptoms that affects up to $90 \%$ of patients with lung cancer (99). This distressing, persistent, and subjective sense of tiredness or exhaustion might be a manifestation of cancer or the side effects of its treatment. Central and peripheral mechanisms could be involved in the development of CRF. The central hypotheses consist of pro-inflammatory cytokine signaling dysregulation, hypothalamic-pituitary-adrenal (HPA) axis disruption, circadian rhythm disorder, serotonin dysregulation, and vagal afferent activation, while, peripheral mechanisms may include ATP dysregulation, muscle metabolism, and effects on contractile properties (100).

Accumulating evidence suggests that inflammation is a common link between CRF and cancer pain. Bone cancer pain enhances the levels of inflammatory factors (TNF- $\alpha$, IL- $1 \beta$, and IL6) via activation of glial cells and central sensitization in the spinal cord (101). Similarly, compared to non-fatigued survivors or healthy controls, fatigued cancer patients had significantly higher levels of pro-inflammatory cytokines, such as C-reactive protein (CRP), IL-1 $\beta$, IL-6, and TNF- $\alpha(102,103)$ in the tumor microenvironment $(104,105)$ or from anti-tumor treatment (radiation therapy or chemotherapy) (106, 107). Enhanced cytokine activity in the periphery might be conveyed to the brain, which in turn would induce central fatigue by altering the serotonin pathway in the brain, influencing the HPA axis, dysregulating circadian rhythms, and inducing vagal afferent activation (108, 109). Symptoms such as fatigue, depression, and loss of appetite, may be the result of peripheral inflammation, mediated by proinflammatory cytokines (110). These cytokines also underlie the development of anemia (111), cachexia (112), and depression (113), which may contribute to CRF. Pain and fatigue share similar inflammatory mechanisms. Thus, fatigue management might utilize P2X antagonists, such as P2X7 selective or specific 
antagonists which have been demonstrated to ameliorate pain and inhibit cytokine release $(66,72,73)$.

In terms of a peripheral hypothesis, limited evidence is available on cancer-related fatigue. However, most patients with cancer suffer from weight loss and/or loss of appetite, which might alter muscle protein metabolism. Peripheral fatigue might be manifested by the inability of muscle, with altered muscle protein metabolism, ATP dysregulation, and contractile properties, to respond to central stimulation (114, 115). The combined products of muscle contraction (ATP, proton, and lactate) activate the sensory neurons innervating skeletal muscle, which might project to the central nervous system via sensory neurons and evoke a sensation of fatigue. Moreover, in an animal model, ATP released from fatigued muscle activates muscle macrophages, which subsequently release IL-1 $\beta$ to produce hyperalgesia. The blockade of P2X4 receptors in muscle inhibits the development of such hyperalgesia (116).

Pilot data suggest that $\mathrm{P} 2 \mathrm{X}$ receptors may act as valid pharmacological targets. To date, the correlation between P2X receptors and cancer-related fatigue has been minimally investigated, and hence, further study of the efficacy of P2X antagonists in treating cancer-related fatigue is needed.

\section{CANCER-RELATED DYSPNEA}

Moderate or severe dyspnea is reported in $20-80 \%$ of cancer patients. Dyspnea is a common symptom in patients with advanced cancer, accompanied by cough due to primary lung cancer in the airway or metastasis of other cancers to the bronchus. Especially, intraluminal tumor in the trachea or a mainstem bronchus activates cough receptors and mechanically obstructs airflow to elicit the sensation of dyspnea (117). Dyspnea is a multifactorial sensation associated with central, peripheral, and chemoreceptor modulation (118). Notably, vagal nerves innervating both the airways and lungs and transmitting to the sensorimotor cortex are capable of inducing dyspnea (119). Several studies have indicated that vagal C-fibers are of dyspneic origin and can be triggered by ATP and adenosine. Furthermore, some A $\delta$ stretch fibers can be directly stimulated by ATP similar to C-fibers $(53,120,121)$. In clinical trials, dyspnea could be evoked by the direct C-fiber activators ATP and adenosine during bronchial challenge testing (122). Inhaling ATP and adenosine induced dyspnea in subjects with asthma (123) and COPD (124). Additionally, intravenous injection of adenosine induced distressing symptoms such as dyspnea, hyperventilation, urge for deep breathing, and chest tightness in healthy volunteers (125), and pre-terminal cancer patients (45, 126). Taken together, extracellular ATP is likely to give rise to dyspnea, and thus may be a potential target for the treatment of dyspnea.

Hypoxemia may be one of the factors stimulating ventilation and producing dyspnea in lung cancer patients (127). Furthermore, central cardiovascular and respiratory neuronal networks are intertwined during and post-hypoxia (128). In knockout P2X2 mice, the activation of the chemoreceptor of the carotid sinus nerve transmits information about arterial $\mathrm{pO}_{2}$ to the respiratory centers of the brain to mediate ventilatory responses to hypoxia. The $\mathrm{P} 2 \mathrm{X} 2$ receptor antagonist PPADS was shown to block neural discharge evoked by hypoxia (129). Furthermore, Zhang et al. reported that suramin, a P2X receptor antagonist, combined with a nicotinic Ach receptor antagonist, blocked the hypoxia-induced increase in chemoreceptor afferent neuronal discharge (130).

Collectively, these studies suggest that the inhibition of specific ATP signal transduction pathways, such as with P2X3 receptor antagonists in the lungs, constitutes an attractive target for the development of new therapies to ameliorate dyspnea. However, additional randomized, double-blinded, placebocontrolled clinical studies are required to confirm whether P2X antagonists are able to eliminate or improve cancerinduced dyspnea.

\section{CONCLUSIONS}

Cancer-related symptoms may significantly and adversely affect patients with lung cancer, causing a marked diminution in the quality of life. Hence, the potential therapeutic roles of P2X receptors in cancer as well as cancer-related symptoms need to be further elucidated. Intratumoral ATP, ATP-P2X receptors, and the vagus nerve are involved in the neuro-immune interactions in cancer. Increased extracellular ATP and its associated compounds activate $\mathrm{P} 2 \mathrm{X}$ receptors expressed on bronchopulmonary nerves to evoke unpleasant sensations (such as the urge to cough, dyspnea, chest tightness, fatigue, and pain) and stimulate/modulate reflexes (such as cough, bronchoconstriction, respiratory rate, and inspiratory drive). Various cancer-related symptoms may share similar pathogenic mechanisms. To date, a significant clinical investigation has established a role for $\mathrm{P} 2 \mathrm{X}$ receptor antagonists in the treatment of chronic cough and cancerrelated pain. Thus, a basis has been formed for the further evaluation of potential therapeutic roles for P2X antagonists in the treatment of other cancer-induced symptoms.

\section{AUTHOR CONTRIBUTIONS}

YM, ZG, and WY drafted the manuscript. NZ, PD, and RC designed and revised the manuscript. All authors contributed to the article and approved the submitted version.

\section{FUNDING}

This study was supported by grants from the National Natural Science Foundation of China (81870079) and National Outstanding Youth Incubation Program of Guangzhou Medical University(2020-207). 


\section{REFERENCES}

1. Neal RD, Sun F, Emery JD, Callister ME. Lung Cancer. BMJ (2019) 365: 11725. doi: 10.1136/bmj.11725

2. Vijayvergia N, Shah PC, Denlinger CS. Survivorship in non-Small Cell Lung Cancer: Challenges Faced and Steps Forward. J Natl Compr Cancer Netw (2015) 13(9):1151-61. doi: 10.6004/jnccn.2015.0140

3. American Cancer Society. Cancer Treatment \& Survivorship Facts \& Figures (2018). Available at: https://www.cancer.org/research/cancer-factsstatistics/survivor-facts-figures.html (Accessed 7 Mar 2018).

4. Dodd MJ, Miaskowski C, Paul SM. Symptom Clusters and Their Effect on the Functional Status of Patients With Cancer. Oncol Nurs Forum (2001) 28:465-70.

5. Molassiotis A, Lowe M, Blackhall F, Lorigan P. A Qualitative Exploration of a Respiratory Distress Symptom Cluster in Lung Cancer: Cough, Breathlessness and Fatigue. Lung Cancer (2011) 71:94-102. doi: 10.1016/ j.lungcan.2010.04.002

6. Chen E, Nguyen J, Cramarossa G, Khan L, Leung A, Lutz S, et al. Symptom Clusters in Patients With Lung Cancer: A Literature Review. Expert Rev Pharmacoecon Outcomes Res (2011) 11:433-9. doi: 10.1586/erp.11.56

7. Luo N, Tan S, Li X, Singh S, Liu S, Chen C, et al. Efficacy and Safety of Opioids in Treating Cancer-Related Dyspnea: A Systematic Review and Meta-Analysis Based on Randomized Controlled Trials. J Pain Symptom Manage (2021) 61:198-210.e1. doi: 10.1016/j.jpainsymman.2020.07.021

8. Molassiotis A, Bailey C, Caress A, Tan J-Y. Interventions for Cough in Cancer. Cochrane Database Syst Rev (2015) 5:CD007881. doi: 10.1002/ 14651858.CD007881.pub3

9. Corli O, Floriani I, Roberto A, Montanari M, Galli F, Greco MT, et al. Are Strong Opioids Equally Effective and Safe in the Treatment of Chronic Cancer Pain? A Multicenter Randomized Phase IV "Real Life" Trial on the Variability of Response to Opioids. Ann Oncol (2016) 27:1107-15. doi: 10.1093/annonc/mdw097

10. Khansari M, Sohrabi M, Zamani F. The Useage of Opioids and Their Adverse Effects in Gastrointestinal Practice: A Review. Middle East J Dig Dis (2013) 5:5-16.

11. Bruera E, Strasser F, Shen L, Palmer JL, Willey J, Driver LC, et al. The Effect of Donepezil on Sedation and Other Symptoms in Patients Receiving Opioids for Cancer Pain: A Pilot Study. J Pain Symptom Manage (2003) 26:1049-54. doi: 10.1016/s0885-3924(03)00332-4

12. Di Virgilio F, Sarti AC, Falzoni S, De Marchi E, Adinolfi E. Extracellular ATP and P2 Purinergic Signalling in the Tumour Microenvironment. Nat Rev Cancer (2018) 18(10):601-18. doi: 10.1038/s41568-018-0037-0

13. Adinolfi E, Capece M, Amoroso F, De Marchi E, Franceschini A. Emerging Roles of P2X Receptors in Cancer. Curr Med Chem (2015) 22(7):878-90. doi: 10.2174/0929867321666141012172913

14. Li J-J, Liu Z-X, Zhang Y-L, Xue G-Y. P2X Receptors and Trigeminal Neuralgia. Neuroreport (2019) 30(10):725-9. doi: 10.1097/WNR.0000000000001266

15. Lara R, Adinolfi E, Harwood CA, Philpott M, Barden JA, Di Virgilio F, et al. P2X7 in Cancer: From Molecular Mechanisms to Therapeutics. Front Pharmacol (2020) 11:793. doi: 10.3389/fphar.2020.00793

16. De Marchi E, Pegoraro A, Adinolfi E. P2X7 Receptor in Hematological Malignancies. Front Cell Dev Biol (2021) 9:645605. doi: 10.3389/ fcell.2021.645605

17. de Rijke B, van Horssen-Zoetbrood A, Beekman JM, Otterud B, Maas F, Woestenenk R, et al. A Frameshift Polymorphism in P2X5 Elicits an Allogeneic Cytotoxic T Lymphocyte Response Associated With Remission of Chronic Myeloid Leukemia. J Clin Invest (2005) 115(12):3506-16. doi: 10.1172/JCI24832

18. Overes IM, de Rijke B, van Horssen-Zoetbrood A, Fredrix H, de Graaf AO, Jansen JH, et al. Expression of P2X5 in Lymphoid Malignancies Results in LRH-1-Specific Cytotoxic T-Cell-Mediated Lysis. Br J Haematol (2008) 141 (6):799-807. doi: 10.1111/j.1365-2141.2008.07125.x

19. Overes IM, Levenga TH, Vos JCM, van Horssen-Zoetbrood A, van der Voort R, De Mulder PH, et al. Aberrant Expression of the HematopoieticRestricted Minor Histocompatibility Antigen LRH-1 on Solid Tumors Results in Efficient Cytotoxic T Cell-Mediated Lysis. Cancer Immunol Immunother (2009) 58(3):429-39. doi: 10.1007/s00262-008-0569-3
20. Schmid S, Kübler M, Korcan Ayata C, Lazar Z, Haager B, Hoßfeld M, et al. Altered Purinergic Signaling in the Tumor Associated Immunologic Microenvironment in Metastasized Non-Small-Cell Lung Cancer. Lung Cancer (2015) 90(3):516-21. doi: 10.1016/j.lungcan.2015.10.005

21. Adinolfi E, Callegari MG, Ferrari D, Bolognesi C, Minelli M, Wieckowski MR, et al. Basal Activation of the P2X7 ATP Receptor Elevates Mitochondrial Calcium and Potential, Increases Cellular ATP Levels, and Promotes Serum-Independent Growth. Mol Biol Cell (2005) 16(7):3260-72. doi: 10.1091/mbc.e04-11-1025

22. Jelassi B, Chantôme A, Alcaraz-Pérez F, Baroja-Mazo A, Cayuela ML, Pelegrin P, et al. P2X(7) Receptor Activation Enhances SK3 Channelsand Cystein Cathepsin-Dependent Cancer Cells Invasiveness. Oncogene (2011) 30(18):2108-22. doi: 10.1038/onc.2010.593

23. Takai E, Tsukimoto M, Harada H, Sawada K, Moriyama Y, Kojima S. Autocrine Regulation of TGF- $\beta 1$-Induced Cell Migration by Exocytosis of ATP and Activation of P2 Receptors in Human Lung Cancer Cells. J Cell Sci (2012) 125(Pt 21):5051-60. doi: 10.1242/jcs.104976

24. Adinolfi E, Raffaghello L, Giuliani AL, Cavazzini L, Capece M, Chiozzi P, et al. Expression of P2X7 Receptor Increases In Vivo Tumor Growth. Cancer Res (2012) 72(12):2957-69. doi: 10.1158/0008-5472.CAN-11-1947

25. Furlan-Freguia C, Marchese P, Gruber A, Ruggeri ZM, Ruf W. P2X7 Receptor Signaling Contributes to Tissue Factor-Dependent Thrombosis in Mice. J Clin Invest (2011) 121(7):2932-44. doi: 10.1172/JCI46129

26. Gilbert SM, Oliphant CJ, Hassan S, Peille AL, Bronsert P, Falzoni S, et al. ATP in the Tumour Microenvironment Drives Expression of Nfp2x7, a Key Mediator of Cancer Cell Survival. Oncogene (2019) 38(2):194-208. doi: 10.1038/s41388-018-0426-6

27. Pegoraro A, De Marchi E, Adinolfi E. P2X7 Variants in Oncogenesis. Cells (2021) 10(1):189. doi: 10.3390/cells10010189

28. Ferrari D, Stroh C, Schulze-Osthoff K. P2X7/P2Z Purinoreceptor-Mediated Activation of Transcription Factor NFAT in Microglial Cells. J Biol Chem (1999) 274(19):13205-10. doi: 10.1074/jbc.274.19.13205

29. Di Virgilio F. Liaisons Dangereuses: P2X(7) and the Inflammasome. Trends Pharmacol Sci (2007) 28(9):465-72. doi: 10.1016/j.tips.2007.07.002

30. Suzuki T, Hide I, Ido K, Kohsaka S, Inoue K, Nakata Y. Production and Release of Neuroprotective Tumor Necrosis Factor by P2X7 ReceptorActivated Microglia. J Neurosci (2004) 24(1):1-7. doi: 10.1523/ JNEUROSCI.3792-03.2004

31. Li X-Y, Moesta AK, Xiao C, Nakamura K, Casey M, Zhang H, et al. Targeting CD39 in Cancer Reveals an Extracellular ATP- and Inflammasome-Driven Tumor Immunity. Cancer Discovery (2019) 9(12):1754-73. doi: 10.1158/ 2159-8290.CD-19-0541

32. Yan J, Li X-Y, Roman Aguilera A, Xiao C, Jacoberger-Foissac C, Nowlan B, et al. Control of Metastases Via Myeloid CD39 and NK Cell Effector Function. Cancer Immunol Res (2020) 8(3):356-67. doi: 10.1158/23266066.CIR-19-0749

33. Hu S, Yu F, Ye C, Huang X, Lei X, Dai Y, et al. The Presence of P2RX7 Single Nuclear Polymorphism Is Associated With a Gain of Function in P2X7 Receptor and Inflammasome Activation in SLE Complicated With Pericarditis. Clin Exp Rheumatol (2020) 38(3):442-9.

34. Zhao C-M, Hayakawa Y, Kodama Y, Muthupalani S, Westphalen CB, Andersen GT, et al. Denervation Suppresses Gastric Tumorigenesis. Sci Transl Med (2014) 6(250):250ra115. doi: 10.1126/scitranslmed.3009569

35. Saloman JL, Albers KM, Li D, Hartman DJ, Crawford HC, Muha EA, et al. Ablation of Sensory Neurons in a Genetic Model of Pancreatic Ductal Adenocarcinoma Slows Initiation and Progression of Cancer. Proc Natl Acad Sci USA (2016) 113(11):3078-83. doi: 10.1073/pnas.1512603113

36. Zhang W-J, Luo C, Pu F-Q, Zhu J-F, Zhu Z. The Role and Pharmacological Characteristics of ATP-Gated Ionotropic Receptor P2X in Cancer Pain. Pharmacol Res (2020) 161:105106. doi: 10.1016/j.phrs.2020.105106

37. Masuda T, Ozono Y, Mikuriya S, Kohro Y, Tozaki-Saitoh H, Iwatsuki K, et al. Dorsal Horn Neurons Release Extracellular ATP in a VNUTDependent Manner That Underlies Neuropathic Pain. Nat Commun (2016) 7(1):12529. doi: 10.1038/ncomms12529

38. Guo L-H, Trautmann K, Schluesener HJ. Expression of P2X4 Receptor in Rat C6 Glioma by Tumor-Associated Macrophages and Activated Microglia. J Neuroimmunol (2004) 152(1-2):67-72. doi: 10.1016/j.jneuroim.2004.04.005 
39. Di Virgilio F, Chiozzi P, Falzoni S, Ferrari D, Sanz JM, Venketaraman V, et al. Cytolytic P2X Purinoceptors. Cell Death Differ (1998) 5(3):191-9. doi: 10.1038/sj.cdd.4400341

40. Di Virgilio F, Schmalzing G, Markwardt F. The Elusive P2x7 Macropore. Trends Cell Biol (2018) 28(5):392-404. doi: 10.1016/j.tcb.2018.01.005

41. Shabbir M, Thompson C, Jarmulowiczc M, Mikhailidis D, Burnstock G. Effect of Extracellular ATP on the Growth of Hormone-Refractory Prostate Cancer In Vivo. BJU Int (2008) 102(1):108-12. doi: 10.1111/j.1464410X.2008.07578.x

42. Bian S, Sun X, Bai A, Zhang C, Li L, Enjyoji K, et al. P2X7 Integrates PI3K/ AKT and AMPK-PRAS40-Mtor Signaling Pathways to Mediate Tumor Cell Death. PloS One (2013) 8(4):e60184. doi: 10.1371/journal.pone.0060184

43. Agteresch HJ, Dagnelie PC, van der Gaast A, Stijnen T, Wilson JH. Randomized Clinical Trial of Adenosine 5'-Triphosphate in Patients With Advanced non-Small-Cell Lung Cancer. J Natl Cancer Inst (2000) 92 (4):321-8. doi: 10.1093/jnci/92.4.321

44. Douguet L, Janho Dit Hreich S, Benzaquen J, Seguin L, Juhel T, Dezitter X, et al. A Small-Molecule P2RX7 Activator Promotes Anti-Tumor Immune Responses and Sensitizes Lung Tumor to Immunotherapy. Nat Commun (2021) 12(1):653. doi: 10.1038/s41467-021-20912-2

45. Beijer S, Gielisse EAR, Hupperets PS, van den Borne BEEM, van den Beuken-van Everdingen M, Nijziel MR, et al. Intravenous ATP Infusions Can Be Safely Administered in the Home Setting: A Study in Pre-Terminal Cancer Patients. Invest New Drugs (2007) 25(6):571-9. doi: 10.1007/s10637007-9076-1

46. McHugh SM, Roman S, Davis B, Koch A, Pickett AM, Richardson JC, et al. Effects of Genetic Variation in the P2RX7 Gene on Pharmacodynamics of a P2X(7) Receptor Antagonist: A Prospective Genotyping Approach. Br J Clin Pharmacol (2012) 74(2):376-80. doi: 10.1111/j.1365-2125.2012.04200.x

47. Sorge RE, Trang T, Dorfman R, Smith SB, Beggs S, Ritchie J, et al. Genetically Determined P2X7 Receptor Pore Formation Regulates Variability in Chronic Pain Sensitivity. Nat Med (2012) 18(4):595-9. doi: 10.1038/ nm. 2710

48. Roger S, Pelegrin P. P2X7 Receptor Antagonism in the Treatment of Cancers. Expert Opin Investig Drugs (2011) 20(7):875-80. doi: 10.1517/ 13543784.2011 .583918

49. Portenoy RK, Lesage P. Management of Cancer Pain. Lancet (1999) 353 (9165):1695-700. doi: 10.1016/S0140-6736(99)01310-0

50. Bellampalli SS, Khanna R. Towards a Neurobiological Understanding of Pain in Neurofibromatosis Type 1: Mechanisms and Implications for Treatment. Pain (2019) 160(5):1007-18. doi: 10.1097/j.pain.00000 00000001486

51. Liu Y, Mikrani R, Xie D, Wazir J, Shrestha S, Ullah R, et al. Chronic Prostatitis/Chronic Pelvic Pain Syndrome and Prostate Cancer: Study of Immune Cells and Cytokines. Fundam Clin Pharmacol (2020) 34(2):160-72. doi: $10.1111 / \mathrm{fcp} .12517$

52. Falk S, Uldall M, Heegaard A-M. The Role of Purinergic Receptors in Cancer-Induced Bone Pain. J Osteoporos (2012) 2012):e758181. doi: 10.1155/2012/758181

53. Ford AP. In Pursuit of P2X3 Antagonists: Novel Therapeutics for Chronic Pain and Afferent Sensitization. Purinergic Signal (2012) 8(Suppl 1):3-26. doi: 10.1007/s11302-011-9271-6

54. Tsuda M, Hasegawa S, Inoue K. P2X Receptors-Mediated Cytosolic Phospholipase A2 Activation in Primary Afferent Sensory Neurons Contributes to Neuropathic Pain. J Neurochem (2007) 103(4):1408-16. doi: $10.1111 /$ j.1471-4159.2007.04861.x

55. North RA. P2X3 Receptors and Peripheral Pain Mechanisms. J Physiol (2004) 554(Pt 2):301-8. doi: 10.1113/jphysiol.2003.048587

56. Burnstock G. Purinergic Receptors and Pain. Curr Pharm Des (2009) 15 (15):1717-35. doi: 10.2174/138161209788186335

57. Liu M, Yang H, Fang D, Yang J-J, Cai J, Wan Y, et al. Upregulation of P2X3 Receptors by Neuronal Calcium Sensor Protein VILIP-1 in Dorsal Root Ganglions Contributes to the Bone Cancer Pain in Rats. Pain (2013) 154 (9):1551-68. doi: 10.1016/j.pain.2013.04.022

58. Wu JX, Xu MY, Miao XR, Lu ZJ, Yuan XM, Li XQ, et al. Functional UpRegulation of P2X3 Receptors in Dorsal Root Ganglion in a Rat Model of Bone Cancer Pain. Eur J Pain (2012) 16(10):1378-88. doi: 10.1002/j.15322149.2012.00149.x
59. Kaan TK, Yip PK, Patel S, Davies M, Marchand F, Cockayne DA, et al. Systemic Blockade of P2X3 and P2X2/3 Receptors Attenuates Bone Cancer Pain Behaviour in Rats. Brain (2010) 133(9):2549-64. doi: 10.1093/brain/ awq194

60. Jarvis MF. Contributions of P2X3 Homomeric and Heteromeric Channels to Acute and Chronic Pain. Expert Opin Ther Targets (2003) 7(4):513-22. doi: 10.1517/14728222.7.4.513

61. Jarvis MF. The Neural-Glial Purinergic Receptor Ensemble in Chronic Pain States. Trends Neurosci (2010) 33(1):48-57. doi: 10.1016/j.tins.2009.10.003

62. Hansen RR, Nasser A, Falk S, Baldvinsson SB, Ohlsson PH, Bahl JMC, et al. Chronic Administration of the Selective P2X3, P2X2/3 Receptor Antagonist, a-317491, Transiently Attenuates Cancer-Induced Bone Pain in Mice. Eur J Pharmacol (2012) 688(1-3):27-34. doi: 10.1016/j.ejphar.2012.05.008

63. Ulmann L, Hatcher JP, Hughes JP, Chaumont S, Green PJ, Conquet F, et al. Up-Regulation of P2X4 Receptors in Spinal Microglia After Peripheral Nerve Injury Mediates BDNF Release and Neuropathic Pain. J Neurosci (2008) 28(44):11263-8. doi: 10.1523/JNEUROSCI.2308-08.2008

64. Suadicani SO, Brosnan CF, Scemes E. P2X7 Receptors Mediate ATP Release and Amplification of Astrocytic Intercellular Ca2+ Signaling. J Neurosci (2006) 26(5):1378-85. doi: 10.1523/JNEUROSCI.3902-05.2006

65. Yang Y, Li H, Li T-T, Luo H, Gu X-Y, Lü N, et al. Delayed Activation of Spinal Microglia Contributes to the Maintenance of Bone Cancer Pain in Female Wistar Rats Via P2X7 Receptor and IL-18. J Neurosci (2015) 35 (20):7950-63. doi: 10.1523/JNEUROSCI.5250-14.2015

66. Chessell IP, Hatcher JP, Bountra C, Michel AD, Hughes JP, Green P, et al. Disruption of the P2X7 Purinoceptor Gene Abolishes Chronic Inflammatory and Neuropathic Pain. Pain (2005) 114(3):386-96. doi: 10.1016/ j.pain.2005.01.002

67. Hansen RR, Nielsen CK, Nasser A, Thomsen SIM, Eghorn LF, Pham Y, et al. P2X7 Receptor-Deficient Mice are Susceptible to Bone Cancer Pain. Pain (2011) 152(8):1766-76. doi: 10.1016/j.pain.2011.03.024

68. Adriouch S, Dox C, Welge V, Seman M, Koch-Nolte F, Haag F. Cutting Edge: A Natural P451L Mutation in the Cytoplasmic Domain Impairs the Function of the Mouse P2X7 Receptor. J Immunol (2002) 169(8):4108-12. doi: 10.4049/jimmunol.169.8.4108

69. Donnelly-Roberts DL, Namovic MT, Han P, Jarvis MF. Mammalian P2X7 Receptor Pharmacology: Comparison of Recombinant Mouse, Rat and Human P2X7 Receptors. Br J Pharmacol (2009) 157(7):1203-14. doi: 10.1111/j.1476-5381.2009.00233.x

70. Orriss I, Syberg S, Wang N, Robaye B, Gartland A, Jorgensen N, et al. Bone Phenotypes of P2 Receptor Knockout Mice. Front Biosci (2011) 3:1038-46. doi: $10.2741 / 208$

71. Syberg S, Petersen S, Beck Jensen J-E, Gartland A, Teilmann J, Chessell I, et al. Genetic Background Strongly Influences the Bone Phenotype of P2X7 Receptor Knockout Mice. J Osteoporos (2012) 2012:391097. doi: 10.1155/ 2012/391097

72. Li P, Zhang Q, Xiao Z, Yu S, Yan Y, Qin Y. Activation of the P2X7 Receptor in Midbrain Periaqueductal Gray Participates in the Analgesic Effect of Tramadol in Bone Cancer Pain Rats. Mol Pain (2018) 14:1744806918803039. doi: $10.1177 / 1744806918803039$

73. Honore P, Donnelly-Roberts D, Namovic M, Zhong C, Wade C, Chandran P, et al. The Antihyperalgesic Activity of a Selective P2X7 Receptor Antagonist, a-839977, Is Lost in IL-1alphabeta Knockout Mice. Behav Brain Res (2009) 204(1):77-81. doi: 10.1016/j.bbr.2009.05.018

74. Guo L-H, Trautmann K, Schluesener HJ. Expression of P2X4 Receptor by Lesional Activated Microglia During Formalin-Induced Inflammatory Pain. J Neuroimmunol (2005) 163(1-2):120-7. doi: 10.1016/j.jneuroim. 2005.03.007

75. Inoue K. The Function of Microglia Through Purinergic Receptors: Neuropathic Pain and Cytokine Release. Pharmacol Ther (2006) 109(12):210-26. doi: 10.1016/j.pharmthera.2005.07.001

76. Yan Y, Liang Y, Ding T, Chu H. PI3K/Akt Signaling Pathway may be Involved in MCP-1-Induced P2X4R Expression in Cultured Microglia and Cancer-Induced Bone Pain Rats. Neurosci Lett (2019) 701:100-5. doi: 10.1016/. .neulet.2019.02.024

77. Harle ASM, Buffin O, Burnham J, Molassiotis A, Blackhall FH, Smith JA. The Prevalence of Cough in Lung Cancer: Its Characteristics and Predictors. J Clin Oncol (2014) 32: suppl 31:162-2. doi: 10.1186/s12885-019-6451-1 
78. Canning BJ. Afferent Nerves Regulating the Cough Reflex: Mechanisms and Mediators of Cough in Disease. Otolaryngol Clin North Am (2010) 43:15-25. doi: 10.1016/j.otc.2009.11.012

79. Canning BJ, Chang AB, Bolser DC, Smith JA, Mazzone SB, McGarvey L, et al. Anatomy and Neurophysiology of Cough: CHEST Guideline and Expert Panel Report. Chest (2014) 146:1633-48. doi: 10.1378/chest.14-1481

80. Sant'Ambrogio G. Afferent Pathways for the Cough Reflex. Bull Eur Physiopathol Respir (1987) 23 Suppl 10:19s-23s

81. Wagland R, Molassiotis A. How Standard Is "Standard Care" in the Symptom Management of Patients With Lung Cancer? The Example of the "Respiratory Distress" Symptom Cluster. Eur J Oncol Nurs. (2011) 15:12. doi: 10.1016/j.ejon.2010.12.001

82. Sarna L, Evangelista L, Tashkin D, Padilla G, Holmes C, Brecht ML, et al. Impact of Respiratory Symptoms and Pulmonary Function on Quality of Life of Long-Term Survivors of Non-Small Cell Lung Cancer. Chest (2004) 125:439-45. doi: 10.1378/chest.125.2.439

83. Yang P, Cheville AL, Wampfler JA, Garces YI, Jatoi A, Clark MM, et al. Quality of Life and Symptom Burden Among Long-Term Lung Cancer Survivors. J Thorac Oncol (2012) 7:64-70. doi: 10.1097/JTO.0b013e3182397b3e

84. Kwong K, Kollarik M, Nassenstein C, Ru F, Undem BJ. P2X2 Receptors Differentiate Placodal vs. Neural Crest C-Fiber Phenotypes Innervating Guinea Pig Lungs and Esophagus. Am J Physiol Lung Cell Mol Physiol (2008) 295:L858-65. doi: 10.1152/ajplung.90360.2008

85. Weigand LA, Ford AP, Undem BJ. A Role for ATP in BronchoconstrictionInduced Activation of Guinea Pig Vagal Intrapulmonary C-Fibres. J Physiol (2012) 590:4109-20. doi: 10.1113/jphysiol.2012.233460

86. Pelleg A, Hurt CM. Mechanism of Action of ATP on Canine Pulmonary Vagal C Fibre Nerve Terminals. J Physiol (1996) 490:265-75. doi: 10.1113/ jphysiol.1996.sp021142

87. Chou Y-L, Mori N, Canning BJ. Opposing Effects of Bronchopulmonary C-Fiber Subtypes on Cough in Guinea Pigs. Am J Physiol Regul Integr Comp Physiol (2018) 314:R489-98. doi: 10.1152/ajpregu.00313.2017

88. Kamei J, Takahashi Y, Yoshikawa Y, Saitoh A. Involvement of P2X Receptor Subtypes in ATP-Induced Enhancement of the Cough Reflex Sensitivity. Eur J Pharmacol (2005) 528:158-61. doi: 10.1016/j.ejphar.2005.10.030

89. Kamei J, Takahashi Y. Involvement of Ionotropic Purinergic Receptors in the Histamine-Induced Enhancement of the Cough Reflex Sensitivity in Guinea Pigs. Eur J Pharmacol (2006) 547:160-4. doi: 10.1016/j.ejphar.2006.07.034

90. Morice AH, Kitt MM, Ford AP, Tershakovec AM, Wu W-C, Brindle K, et al. The Effect of Gefapixant, a P2X3 Antagonist, on Cough Reflex Sensitivity: A Randomised Placebo-Controlled Study. Eur Respir J (2019) 54:1900439. doi: 10.1183/13993003.00439-2019

91. Bonvini SJ, Birrell MA, Grace MS, Maher SA, Adcock JJ, Wortley MA, et al. Transient Receptor Potential Cation Channel, Subfamily V, Member 4 and Airway Sensory Afferent Activation: Role of Adenosine Triphosphate. J Allergy Clin Immunol (2016) 138:249-61.e12. doi: 10.1016/j.jaci.2015.10.044

92. Abdulqawi R, Dockry R, Holt K, Layton G, McCarthy BG, Ford AP, et al. P2X3 Receptor Antagonist (AF-219) in Refractory Chronic Cough: A Randomised, Double-Blind, Placebo-Controlled Phase 2 Study. Lancet (2015) 385:1198-205. doi: 10.1016/S0140-6736(14)61255-1

93. Smith JA, Kitt MM, Morice AH, Birring SS, McGarvey LP, Sher MR, et al. Gefapixant, A P2X3 Receptor Antagonist, for the Treatment of Refractory or Unexplained Chronic Cough: A Randomised, Double-Blind, Controlled, Parallel-Group, Phase 2b Trial. Lancet Respir Med (2020) 8:775-85. doi: 10.1016/S2213-2600(19)30471-0

94. Muccino DR, Morice AH, Birring SS, Dicpinigaitis PV, Pavord ID, Assaid C, et al. Design and Rationale of Two Phase 3 Randomised Controlled Trials (COUGH-1 and COUGH-2) of Gefapixant, a P2X3 Receptor Antagonist, in Refractory or Unexplained Chronic Cough. ERJ Open Res (2020) 6:002842020. doi: $10.1183 / 23120541.00284-2020$

95. McGarvey L, Birring S, Morice A, Dicpinigaitis P, Pavord I, Schelfhout J, et al. Late Breaking Abstract-Two Phase 3 Randomized Clinical Trials of Gefapixant, a P2X3 Receptor Antagonist, in Refractory or Unexplained Chronic Cough (COUGH-1 and COUGH-2). Eur Respir J (2020) 56 Suppl:64, 3800 .

96. Garceau D, Chauret N. BLU-5937: A Selective P2X3 Antagonist With Potent Anti-Tussive Effect and No Taste Alteration. Pulm Pharmacol Ther (2019) 56:56-62. doi: 10.1016/j.pupt.2019.03.007
97. Morice AH, Smith JA, McGarvey L, Birring SS, Parker SM, Turner A, et al. Safety and Efficacy of BAY 1817080, A P2X3 Receptor Antagonist, in Patients With Refractory Chronic Cough (RCC). Am J Respir Crit Care Med (2020) 201:A7648.

98. Niimi A, Ishihara H, Hida H, Miyazaki S. Phase 2a Randomized, DoubleBlind, Placebo-Controlled, Crossover Study of a P2X3 Receptor Antagonist s-600918: Effects on Health-Related Quality of Life in Patients With Refractory Chronic Cough [Abstract]. Am J Respir Crit Care Med (2020) 201:A7647.

99. Borneman T, Piper BF, Sun VC-Y, Koczywas M, Uman G, Ferrell B. Implementing the Fatigue Guidelines At One NCCN Member Institution: Process and Outcomes. J Nat Compr Canc Netw (2007) 5:1092-101. doi: 10.6004/jnccn.2007.0090

100. O’Higgins CM, Brady B, O'Connor B, Walsh D, Reilly RB. The Pathophysiology of Cancer-Related Fatigue: Current Controversies. Support Care Cancer (2018) 26:3353-64. doi: 10.1007/s00520-018-4318-7

101. Zhang T, Sun K, Shen W, Qi L, Yin W, Wang L-W. SOCS1 Regulates Neuropathic Pain by Inhibiting Neuronal Sensitization and Glial Activation in Mouse Spinal Cord. Brain Res Bull (2016) 124:231-7. doi: 10.1016/ j.brainresbull.2016.05.012

102. Bower JE, Ganz PA, Aziz N, Fahey JL. Cole SW. T-Cell Homeostasis in Breast Cancer Survivors With Persistent Fatigue. J Natl Cancer Inst (2003) 95:1165-8. doi: 10.1093/jnci/djg0019

103. Schubert C, Hong S, Natarajan L, Mills PJ, Dimsdale JE. The Association Between Fatigue and Inflammatory Marker Levels in Cancer Patients: A Quantitative Review. Brain Behav Immun (2007) 21:413-27. doi: 10.1016/ j.bbi.2006.11.004

104. Balkwill F, Mantovani A. Inflammation and Cancer: Back to Virchow? Lancet (2001) 357:539-45. doi: 10.1016/S0140-6736(00)04046-0

105. Balkwill F. Cancer and the Chemokine Network. Nat Rev Cancer (2004) 4:540-50. doi: $10.1038 / \mathrm{nrc1} 388$

106. Bower JE, Ganz PA, Tao ML, Hu W, Belin TR, Sepah S, et al. Inflammatory Biomarkers and Fatigue During Radiation Therapy for Breast and Prostate Cancer. Clin Cancer Res (2009) 15:5534-40. doi: 10.1158/1078-0432.CCR-082584

107. Chou HL, Chao TY, Chen TC, Chu CM, Hsieh CH, Yao CT, et al. The Relationship Between Inflammatory Biomarkers and Symptom Distress in Lung Cancer Patients Undergoing Chemotherapy. Cancer Nurs (2017) 40: E1-8. doi: 10.1097/NCC.0000000000000369

108. Bower JE, Ganz PA, Dickerson SS, Petersen L, Aziz N, Fahey JL. Diurnal Cortisol Rhythm and Fatigue in Breast Cancer Survivors. Psychoneuroendocrinology (2005) 30:92-100. doi: 10.1016/j.psyneuen.2004.06.003

109. Jager A, Sleijfer S, van der Rijt CCD. The Pathogenesis of Cancer Related Fatigue: Could Increased Activity of Pro-Inflammatory Cytokines be the Common Denominator? Eur J Cancer (2008) 44:175-81. doi: 10.1016/j.ejca.2007.11.023

110. Dantzer R. Cytokine-Induced Sickness Behaviour: A Neuroimmune Response to Activation of Innate Immunity. Eur J Pharmacol (2004) 500:399-411. doi: 10.1016/j.ejphar.2004.07.040

111. Kurzrock R. The Role of Cytokines in Cancer-Related Fatigue. Cancer (2001) 92(Suppl 6):1684-8. doi: 10.1002/1097-0142(20010915)92:6+<1684::aidcncr1497>3.0.co;2-z

112. Quesada JR, Talpaz M, Rios A, Kurzrock R, Gutterman JU. Clinical Toxicity of Interferons in Cancer Patients: A Review. J Clin Oncol (1986) 4:234-43. doi: 10.1200/JCO.1986.4.2.234

113. Maes M, Meltzer HY, Bosmans E, Bergmans R, Vandoolaeghe E, Ranjan R, et al. Increased Plasma Concentrations of Interleukin-6, Soluble Interleukin6, Soluble Interleukin-2 and Transferrin Receptor in Major Depression. J Affect Disord (1995) 34:301-9. doi: 10.1016/0165-0327(95)00028-1

114. Taylor JL, Todd G, Gandevia SC. Evidence for a Supraspinal Contribution to Human Muscle Fatigue. Clin Exp Pharmacol Physiol (2006) 33:400-5. doi: 10.1111/j.1440-1681.2006.04363.x

115. Yavuzsen T, Davis MP, Ranganathan VK, Walsh D, Siemionow V, Kirkova J, et al. Cancer-Related Fatigue: Central or Peripheral? J Pain Symptom Manage (2009) 38:587-96. doi: 10.1016/j.jpainsymman.2008.12.003

116. Oliveira-Fusaro MC, Gregory NS, Kolker SJ, Rasmussen L, Allen LH, Sluka KA. P2X4 Receptors on Muscle Macrophages Are Required for Development of Hyperalgesia in an Animal Model of Activity-Induced Muscle Pain. Mol Neurobiol (2020) 57:1917-29. doi: 10.1007/s12035-019-01852-x 
117. Kvale PA. Chronic Cough Due to Lung Tumors: ACCP Evidence-Based Clinical Practice Guidelines. Chest (2006) 129 Suppl 1:147S-53S. doi: 10.1378/chest.129.1_suppl.147S

118. Buchanan GF, Richerson GB. Role of Chemoreceptors in Mediating Dyspnea. Respir Physiol Neurobiol (2009) 167:9-19. doi: 10.1016/ j.resp.2008.12.002

119. Burki NK, Lee L-Y. Mechanisms of Dyspnea. Chest (2010) 138:1196-201. doi: 10.1378/chest.10-0534

120. Burki NK, Lee LY. Blockade of Airway Sensory Nerves and Dyspnea in Humans. Pulm Pharmacol Ther (2010) 23:279-82. doi: 10.1016/j.pupt.2010.02.002

121. Undem BJ, Nassenstein C. Airway Nerves and Dyspnea Associated With Inflammatory Airway Disease. Respir Physiol Neurobiol (2009) 167:36-44. doi: 10.1016/j.resp.2008.11.012

122. Marks GB, Yates DH, Sist M, Ceyhan B, De Campos M, Scott DM, et al. Respiratory Sensation During Bronchial Challenge Testing With Methacholine, Sodium Metabisulphite, and Adenosine Monophosphate. Thorax (1996) 51:793-8. doi: 10.1136/thx.51.8.793

123. Basoglu OK, Pelleg A, Essilfie-Quaye S, Brindicci C, Barnes PJ, Kharitonov SA. Effects of Aerosolized Adenosine 5"-Triphosphate vs Adenosine 5"Monophosphate on Dyspnea and Airway Caliber in Healthy Nonsmokers and Patients With Asthma. Chest (2005) 128:1905-9. doi: 10.1378/ chest.128.4.1905

124. Basoglu OK, Barnes PJ, Kharitonov SA, Pelleg A. Effects of Aerosolized Adenosine $5^{\prime}$-Triphosphate in Smokers and Patients With COPD. Chest (2015) 148:430-5. doi: 10.1378/chest.14-2285

125. Burki NK, Sheatt M, Lee LY. Effects of Airway Anesthesia on Dyspnea and Ventilatory Response to Intravenous Injection of Adenosine in Healthy Human Subjects. Pulm Pharmacol Ther (2008) 21:208-13. doi: 10.1016/ j.pupt.2007.02.004
126. Haskell CM, Mendoza E, Pisters KM, Fossella FV, Figlin RA. Phase II Study of Intravenous Adenosine 5'-Triphosphate in Patients With Previously Untreated Stage IIIB and Stage IV non-Small Cell Lung Cancer. Invest New Drugs (1998) 16:81-5. doi: 10.1023/a:1006018610986

127. Meriggi F. Dyspnea in Cancer Patients: A Well-Known and Neglected Symptom. Rev Recent Clin Trials (2018) 13:84-8. doi: 10.2174/ 1574887113666180326112116

128. Dergacheva O, Griffioen KJ, Neff RA, Mendelowitz D. Respiratory Modulation of Premotor Cardiac Vagal Neurons in the Brainstem. Respir Physiol Neurobiol (2010) 174:102-10. doi: 10.1016/j.resp.2010.05.005

129. Rong W, Gourine A, Cockayne DA, Xiang Z, Ford AP, Spyer KM, et al. Pivotal Role of Nucleotide P2X2 Receptor Subunit Mediating Ventilatory Responses to Hypoxia: Knockout Mouse Studies. J Neurosci (2003) 23:11315-21. doi: 10.1523/JNEUROSCI.23-36-11315.2003

130. Zhang M, Zhong H, Vollmer C, Nurse CA. Co-Release of ATP and Ach Mediates Hypoxic Signalling at Rat Carotid Body Chemoreceptors. J Physiol (2000) 525:143-58. doi: 10.1111/j.1469-7793.2000.t01-1-00143.x

Conflict of Interest: The authors declare that the research was conducted in the absence of any commercial or financial relationships that could be construed as a potential conflict of interest.

Copyright (c) 2021 Mai, Guo, Yin, Zhong, Dicpinigaitis and Chen. This is an openaccess article distributed under the terms of the Creative Commons Attribution License (CC BY). The use, distribution or reproduction in other forums is permitted, provided the original author(s) and the copyright owner(s) are credited and that the original publication in this journal is cited, in accordance with accepted academic practice. No use, distribution or reproduction is permitted which does not comply with these terms. 